Georgetown University Law Center

Scholarship @ GEORGETOWN LAW

1991

\title{
Genetic Discrimination: The Use of Genetically Based Diagnostic and Prognostic Tests by Employers and Insurers
}

Lawrence O. Gostin

Georgetown University Law Center, gostin@law.georgetown.edu

This paper can be downloaded free of charge from:

https://scholarship.law.georgetown.edu/facpub/763

17 Am. J.L. \& Med. 109-144 (1991)

This open-access article is brought to you by the Georgetown Law Library. Posted with permission of the author. Follow this and additional works at: https://scholarship.law.georgetown.edu/facpub

Part of the Bioethics and Medical Ethics Commons, Civil Rights and Discrimination Commons, Health Law and Policy Commons, Health Policy Commons, Public Health Commons, and the Public Policy Commons 


\title{
Genetic Discrimination: The Use of Genetically Based Diagnostic and Prognostic Tests by Employers and Insurers*
}

\author{
Larry Gostin**
}

Genetic discrimination is detrimental to public health programs, as well as to society generally. Advances in genetic testing and screening, accelerated and prompted by the Human Genome Initiative, increase society's ability to detect and monitor chromosomal differences. These technologies and their resulting genomic data will enhance medical science, but may also encourage discrimination. Although few employers or insurers currently utilize genetic screening, testing or data, rising employee benefit costs and market forces create powerful incentives for usage.

Current municipal, state and federal laws, including the Americans with Disabilities Act (ADA), may not sufficiently protect employees and insureds from genetic discrimination. While municipal and state protections should not be overlooked, the ADA's sweeping scope may currently provide the most comprehensive safeguard. Federal laws banning discrimination on the basis of race or sex might also successfully redress some forms of genetic discrimination. Genetic technologies' advent necessitates efforts to rectify state and federal statutory coverage gaps, strictly regulate employers and produce comprehensive guidelines regarding its use.

\section{INTRODUCTION}

The Human Genome Initiative places squarely before society a set of legitimate values that conflicts with the anti-discrimination principle. ${ }^{1}$ This paper analyzes the law, ethics and public policy concerning

\footnotetext{
- An earlier version of this paper was written for the National Center for Human Genome Research, Working Group on Ethical, Legal, and Social Issues Related to Mapping and Sequencing the Human Genome. I would like to thank Alissa Spielberg for her research assistance on the project.

* Executive Director, American Society of Law \& Medicine.

I See Liebman, Too Much Information: Predictions of Employee Disease and the Fringe Benefit Sys-
} 
"genetic discrimination," defined as the denial of rights, privileges or opportunities on the basis of information obtained from geneticallybased diagnostic and prognostic tests. ${ }^{2}$ The Human Genome Initiative will enhance the ability to gather and organize information that may predict a person's future potential and disabilities. Enormous human benefits may ensue from understanding the etiology and pathophysiology of genetic disorders, ${ }^{3}$ including disease prevention through genetic counseling, and treatment of the disorders through genetic manipulation. ${ }^{4}$ This information will help clinicians understand and eventually treat many of the more than 4,000 diseases known to be caused by single-gene defects, ${ }^{5}$ as well as multifactorial diseases. ${ }^{6}$

Unfortunately, the Human Genome Initiative also has potential for social detriment. One day, employers and insurers will be able to obtain a genetic profile from the blood drawn from a small finger prick. ${ }^{7}$ This profile will go beyond discrete conditions, such as Huntington disease, sickle cell, cystic fibrosis and Duchene muscular dystrophy. The employer may further analyze an employee's susceptibility to a wide range of physical conditions such as cancer, heart disease, Alzheimer's disease and schizophrenia. ${ }^{8}$

As our ability to detect genetic defects or propensities toward illness increases, so too does the threat that such detection will be used to discriminate. Prejudice, alienation and exclusion often accompany ge-

tem, 1988 U. ChI. Legal F. 57 (reviewing the development of the anti-discrimination principle).

${ }^{2}$ See P. Billings, M. Kohn, M. de Cuevas \& J. Beckwith, Genetic Discrimination as a Consequence of Genetic Screening 6 (Oct. 24, 1990) (unpublished manuscript), to be published in Aм. J. Hum. Genetics (1991) [hereinafter Billings] (defining genetic discrimination as "differential treatment based on apparent or perceived human variation presumed to have a genetic origin").

${ }^{3}$ Etiology is the science of the causes or origins of diseases. Stedman's Medical DicTIONARY 489 (4th unabridged ed. 1976). Pathophysiology is the branch of biology dealing with the functions and vital processes of disease. Id. at 1041.

4 See generally Antonarakis, The Mapping and Sequencing of the Human Genome, 83 S. MED. J. 876, 878 (1990); Goldstein \& Brown, Genetic Aspects of Disease, in Harrison's Principles of Internal Medicine 285 (E. Braunwald, K. Isselbacher, R. Peterdorf, J. Wilson, J. Martin \& A. Fauci eds. 1987).

5 U.S. Dep't of Health \& Hum. Servs. (Public Health Service, National Insts. of Health, National Center for Hum. Genome Res.) \& U.S. Dep'r of ENERGY (Office of Energy Res., Office of Health \& Envtl. Res., Human Genome Program), Understandinc: Our Genetic Inheritance: The U.S. Human Genome Project: The First Five Years FY 1991-1995 vii (1990) [hereinafter The Human Genome Project].

6 Id.

${ }^{7}$ See Hening, Body and Mind: High-Tech Fortunetelling, N.Y. Times, Dec. 24, 1989, § 6 (Magazine), at 20; Liebman, supra note 1, at 60.

8 Liebman, supra note 1, at 60 ("Suddenly the job applicant is not a member of an undifferentiated population ... [but has] a statistically analyzable medical future:"). See also J. Bishop \& M. WALDholz, Genome 285-306 (1990) (describing incidences where genetic screening has been used). 
netically related diseases even though, by definition, the condition is neither subject to the person's control, nor the result of willful behavior. The fact that genetic diseases are sometimes closely associated with discrete ethnic or racial groups such as African Americans, ${ }^{9}$ Ashkenazi Jews ${ }^{10}$ or Armenians ${ }^{11}$ compounds the potential for invidious discrimination. ${ }^{12}$ Preventing discrimination based upon a person's health care status, and providing equal opportunities for persons with disease and disability are both powerful societal goals fully recognized by Congress ${ }^{13}$ and the courts. ${ }^{14}$

The demand for genomic information, however, can be rational. Genomic data can promote the health of people having genetic predispositions to disease by excluding them from hazardous environments; ensure that workers are fit for employment by requiring them to meet qualification standards; and save costs, by not hiring persons having a high probability of disproportionately burdening company benefit plans. In an age when large employers pay as much, or more, for health and welfare benefits as for the raw materials of production, they are anxious to improve productivity and lower personnel costs. ${ }^{15}$ Thus, decisions based on genetic information cannot always be attributed to pernicious myths, irrational fears or ethnic hatred. The Human Genome Initiative therefore accelerates societal conflict between the rights of individuals and institutions. ${ }^{16}$

This paper explores the legal and ethical constraints that ensure genomic information is used only to protect a person's health or safety, or enforce legitimate job, service or benefit criteria. This paper reviews the scope, prevalence and potential of genetic discrimination, and why such discrimination violates fundamental principles of human rights and undermines the public health goals that are the true promise of the Genome Initiative. The paper then examines whether the Americans with Disabilities Act and the corpus of anti-discrimination law are suffi-

\footnotetext{
${ }^{9}$ E.g., sickle cell disease.

${ }^{10}$ E.g., Bloom's Syndrome, Gaucher's disease (adult form), Tay-Sachs disease.

11 E.g., Familial Mediterranean fever.

12 See generally Goldstein \& Brown, supra note 4, at 588 (Table 57-1: Examples of simply inherited disorders that occur with increased frequency in specific ethnic groups); see also $\mathrm{T}$. Duster, BAckdoor to Eugenics 160-62 (1990) (Appendix C: The Ethnic Distribution of Disease).

13 See Americans with Disabilities Act of 1990 (ADA), Pub. L. No. 101-336, 104 Stat. 376 (codified in scattered sections of 29 U.S.C.A., 47 U.S.C.A. and 42 U.S.C.A. $\$ \$ 12101-12213$ (West Supp. 1990)).

14 See School Bd. of Nassau County v. Arline, 480 U.S. 273, reh'g denied, 481 U.S. 1024 (1987).

15 See generally Rothstein, Employee Selection Based on Susceptibility to Occupational Illness, 81 Mich. L. Rev. 1379 (1989).

I6 See generally Beckwith, The Human Genome Initiative: Genetics' Lightning Rod, 17 AM. J.L. \& MED, 1 (1991).
} 
ciently relevant and comprehensive to safeguard against genetic discrimination. As part of this examination, the paper will discuss genetic discrimination in two key sectors: employment and insurance. Finally, the paper proposes future legislative and judicial safeguards against genetic discrimination.

\section{PREVALENCE OF AND POTENTIAL FOR GENETIC DISCRIMINATION: JUSTICE AND PUBLIC HEALTH CONSTEQUENCES}

Amidst euphoria generated by the Human Genome Initiative, the National Institutes of Health ${ }^{17}$ and the Congress ${ }^{18}$ have expressed concern that genomic information may result in stigmatization and discrimination. Indeed, fear of the social impact of the human genome's discovery may be the most significant impediment to continued full funding of the project. ${ }^{19}$ Fortunately, most funders appreciate that, while fear of unknown medical advances does not justify stifling scientific progress, careful ethical planning and legal safeguards are required.

\section{A. The Social Impact of Genetic Discrimination}

Genetic discrimination violates basic tenets of individual justice and is detrimental to public health. Discrimination based upon actual or perceived genetic characteristics denies an individual equal opportunity because of a status over which she has no control. Discrimination based on genetic factors can be as unjust as that based on race, gender or disability. In each case, people are treated inequitably, not because of their inherent abilities, but solely because of pre-determined characteristics. The right to be treated equally and according to one's abilities in all the diverse aspects of human endeavor is a core social value.

Genetic discrimination is harmful not merely because it violates core social values, but also because it thwarts the creativity and productivity of human beings, perhaps more than the disability itself. By excluding qualified individuals from education, employment, government service or insurance, the marketplace is robbed of skills, energy and

17 See The Human Genome Project, supra note 5, at 20-21, 65-73 (Report of the Working Group on Ethical, Legal, and Social Issues Related to Mapping and Sequencing the Human Genome).

18 See id. at 65; 136 Cong. Rec. H4996, H5003 (daily ed. July 19, 1990) (statement of Rep. Obey) (the human genome project may divide us into "two groups, those with pluperfect and imperfect genes. . . . Taxpayers should not be put in the position of financing government programs without protections to ensure that those programs will not in the end lead to fencing them out of jobs or reasonably priced health insurance." We need to develop legal and ethical safeguards "before the knowledge genie is completely out of the bottle.").

19 See 136 Cong. Rec. H5003 (daily ed. July 19, 1990). 
imagination. Such exclusion promotes physical and economic dependency, draining rather than enriching social institutions. Finally, genetic discrimination also undercuts the Human Genome Initiative's fundamental purpose of promoting the public health. ${ }^{20}$ Infusing human and financial resources into the Genome Initiative is justified by the promise of clinical benefits in identifying, preventing and effectively intervening in human disease. ${ }^{21}$ If fear of discrimination deters people from genetic diagnosis and prognosis, renders them less willing to confide in physicians and genetic counselors, and makes them more concerned with loss of a job or insurance than with care and treatment, the benefits of genetic data collection will not be fully achieved.

Discrimination's public health impact will become clearer as genetic technology advances. The public health justification for widespread collection and utilization of genomic data will increase as genetic diagnosis and prognosis become more accurate and less expensive, and as gene therapies become standard medical practice. Society's ability to develop and implement ambitious genetic screening and intervention strategies will depend upon the adequacy of safeguards against breaches of confidence and discrimination.

\section{B. Discrimination and ScIEnTIFIC UnCERTAinty}

Complex and often pernicious mythologies emerge from public ignorance of genetically-based diagnostic and prognostic tests. The common belief is that genetic technologies generated from scientific assessment are always accurate, highly predictive and capable of identifying an individual's or offspring's inevitable pre-destination of future disability. The facts are diametrically opposed to this common belief. The results of genetic-based diagnosis and prognosis are uncertain for many reasons. The sensitivity of genetic testing is limited by the known mutations in a target population. ${ }^{22}$ For example, screening can currently detect only seventy-five percent of Cystic Fibrosis (CF) chromosomes in the U.S. white population. ${ }^{23}$ In only fifty-six percent of at-risk

20 The human Genome Project, supra note 5, at vii, 20.

21 See Watson, The Human Genome Project: Past, Present, and Future, 248 Science 44 (1990).

22 See generally McKusick, Mendelian Disorders, in The Principles and Practice of Medicine 281, 281.89 (A. Harvey, R. Johns, V. McKusick, A. Owens \& R. Ross eds. 1988) [hereinafter The Principles and Practice of Medicine].

${ }^{23}$ Wilfond \& Fost, The Cystic Fibrosis Gene: Medical and Social Implications for Heterozygote Detection, 263 J. A.M.A. 2777, 2779 (1990). A genetic condition such as Cystic Fibrosis (CF) is caused by mutations in the DNA which produce the disease. Tests for CF seek to identify the known mutations. J. Bishop \& M. WAldholz, supra note 8, at 289-290. Screening for CF is now very much on the public agenda, despite cautionary statements by the Public Health Service and professional organizations. The American Sociely of Human Genetics Statement on Cystic Fibrosis Screening, 46 AM. J. Hum. Generics 393 (1990); Statement from the National Insitutes of 
couples will both persons be identified as carriers. ${ }^{24}$ Professors Wilfond and Fost calculate that one out of every two couples from the general population identified by CF population screening as "at risk" will be falsely labeled, and therefore, may experience increased anxiety or discrimination, or needlessly alter their reproductive plans. ${ }^{25}$

Predicting the nature, severity and course of disease based upon a genetic marker is an additional difficulty. For most genetic diseases the onset date, severity of symptoms, and efficacy of treatment and management are highly variable. Some people remain virtually symptom free, while others progress to seriously disabling illness. A marker for Huntington chorea, for example, presents an aura of inevitable relentless and progressive neurologic impairment but, in fact, great variability appears even among cases diagnosed within the same family. ${ }^{26}$ Neurofibromatosis manifests itself with similar variability, as some will suffer marked disability of the nervous system, muscles, bones and skin, while others will exhibit minor pigmented spots on their body. ${ }^{27}$ Additionally, many gene-associated diseases, unlike CF and Huntington, are multifactorial and not attributed to a single gene mutation or genetic marker. Their appearance can depend upon complex interactions of genetic and environmental factors that cannot be accurately measured. Current scientific assessments point to numerous, poorly understood, multifactorial diseases ranging from colon cancer, heart disease and emphysema, to schizophrenia, depression and alcoholism. ${ }^{28}$

Genetic-based diagnosis and prognosis, therefore, is heterogeneous. The reliability and predictive value of genetic tests are limited by the extent to which mutations are known and prevalent in the target population. Variability exists in the onset, presentation and outcome of disease, and predictions are confounded by a multiplicity of genetic, biomedical and environmental factors. For all these reasons, significant scientific uncertainty surrounds much genetic testing.

Genomic information may be highly beneficial for patients and health care professionals in areas related to prevention, treatment, diet,

Health Workshop on Population Screening for the Cystic Fibrosis Gene, 323 NEw ENG. J. MED. 70 (1990) [hereinafter NIH Consensus Statement].

24 Wilfond \& Fost, supra note 23, at 2779.

${ }^{25}$ Id. at 2781 . Professor Billings and his colleagues recount a case of a family with a child who has CF and received care through an HMO. When a second pregnancy occurred, a prenatal DNA test was positive for two copies of the CF gene. The HMO considered withdrawal of coverage if the family proceeded with the pregnancy. Threats of legal action were required before the HMO agreed to continue coverage. Billings, supra note 2, at 18 .

26 De Long \& Moses, Disorders of Movement, in The Principles and Practice of Medicine, supra note 22, at $1057,1069$.

27 McKusick, supra note 22, at 286-87.

28 See generally McKusick, Multifactorial Disorders: The Genetics of Common Diseases, in THE Principles and Practices of Medicine, supra note 22, at 303. 
lifestyle or reproductive choices. Employers, insurers, educators, police and others, however, will surely come to have access to genomic information. When genomic information is used by social institutions, not to prevent or treat disease, but to deny opportunity, exclude from work or benefits, remove health care coverage or restrict liberty, a whole new dimension to the Genome Initiative becomes apparent. Adverse employment and insurance decisions are particularly hurtful when rendered on the basis of false assumptions regarding the nature, accuracy and predictability of genetic tests.

\section{Genetic Screenning and Monitoring}

The U.S. Congress Office of Technology Assessment (OTA) provides the only systematic data concerning past, current and future use of workplace genetic screening and monitoring. ${ }^{29} \mathrm{~A}$ comparable population of industrial companies, utilities and trade unions were surveyed in 1982 and 1989 to provide trend data. The OTA surveys show that relatively few companies currently utilize genetic screening and monitoring. In the 1989 survey, twenty health officers from the 330 Fortune 500 companies responding (six percent) reported the use of genetic monitoring or screening. Of these, twelve companies were conducting monitoring or screening, and eight had done so in the past. In 1982, six companies were currently using the technology, while twelve had previously done so. ${ }^{30}$ The rate of current to past monitoring and screening was reversed from 1982 to 1989 , with twice the number of companies currently using genomic information in 1989 than in $1982 .{ }^{31}$

If there has been little or no real growth in the number of companies conducting genetic monitoring and screening in the workplace, what do companies foresee for the future? In 1982, fifty-five companies said they might use genomic information within the next five years. ${ }^{32}$

\footnotetext{
29 See, e.g., Office of Tech. Assessment, U.S. Conc., Genetic Monitoring and ScreenING IN THE WORKPLACE $171-88$ (1990) [hereinafter OTA 1990 Report]; OfFICE OF TeCh. Assessment, U.S. Cong., The Role of Genetic Testinc in the Prevention of Occupational DiseASE 33-46 (1983) [hereinafter OTA 1983 REPORT]. Genetic testing includes a number of technologies to detect genetic traits, changes in chromosomes, or changes in DNA. The OTA distinguishes between two different kinds of genetic testing: examining persons for evidence of induced change in their genetic material (monitoring) and identifying individuals with particular inherited traits or disorders (screening). OTA 1990 REPORT, supra, at 3-6. The OTA terminology is somewhat confusing from a public health perspective since testing usually refers to case identification of an individual, while screening involves more systematic application to whole populations. See Gostin, Curran \& Clark, The Case Against Compulsory Casefinding in Controlling AIDS: Testing, Screening and Reporting, 12 AM. J.L. \& MED. 7, 10-11 (1987).

30 OTA 1990 REPORT, supra note 29, at 175-76.

31 Id. at 176,178 . But note that " $[t]$ he increase in the number of 'current users' in 1989 could reflect slight differences in question wording between the two surveys." $I d$. at 176 .

32 OTA 1983 REPORT, supra note 29 , at 34.
} 
OTA reports that fewer companies anticipated using genetic testing and monitoring in 1989 than in $1982 .{ }^{33}$ However, in a survey of 400 firms conducted in 1989 by Northwestern National Life Insurance Company, fifteen percent of companies responded that by the year 2000 they planned to check the genetic status of prospective employees and their dependents before making employment offers. ${ }^{34}$

The only available data from the insurance industry is consistent with the findings of the OTA employment surveys. In 1989, the American Council on Life Insurance conducted the first study to determine the industry's use of genetic testing. The Council reported that no insurance company performed its own tests, but some accessed known genomic information in their underwriting decisions. ${ }^{35}$ The Health Insurance Association of America has formed its own committee and plans to survey its members on the use of genetic testing. ${ }^{36}$

The absence of the expected growth in genetic testing and monitoring by industry and insurers should not provide grounds for complacency. Employers and insurers utilizing genetic testing did so based upon its predictive value, scientific consensus and cost. ${ }^{97}$ The Human Genome Initiative's promotion of rapid progress in human molecular genetics suggests increased occupational and insurance use in the future. While industry and insurers are unlikely to routinely use genetic diagnosis that costs, say, $\$ 2,000-\$ 3,000$ per test, as the technology becomes capable of identifying a battery of genetic conditions at a fraction of the current cost, the sheer competitive nature of industry and insurance may drive them toward increased testing. American industry is likely to turn to genetic diagnosis in the future for many of the same reasons that have driven the sharp increases in drug, polygraph and general medical testing in the workplace. ${ }^{38}$

In the end, market forces may be the single greatest factor motivat-

33 OTA 1990 REPORT, supra note 29, at 178, 183.

34 Brownlee \& Silberner, The Assurances of Genes, U.S. News \& WorLd REP., July 23, 1990, at 57.

35 R. Pokorski, The Potential Role of Genetic Testinc in Risk Classification (American Council of Life Ins. 1990). See Sit, Will Genetic Mapping Threaten Workers' Privacy?, Boston Globe, Aug. 21, 1990, at 23, col. 1.

${ }^{36}$ J. Payne, Working Group on Genetic Testing (Health Insurance Ass'n of Am. 1990).

37 OTA 1983 REPORT, supra note 29, at 36 . The OTA found, however, that none of the genetic tests evaluated at that time met established scientific criteria for routine use in an occupational setting. OTA 1990 REPORT, supra note 29 , at 8 . The chasm in perception between the OTA and industry appears to be the employer's willingness to assume that if tests are sufficiently reliable for clinical use, they can safely be used in occupational settings. See Prediction and Prejudice: Forging a New Underclass, 55 Consumer ReP. 483 (1990).

${ }^{38}$ A comprehensive OTA report on testing in health insurance documents the substantial rise in testing, including prospects for genetic testing. Office of Tech. Assessment, U.S Conc., Medical Testing and Health Insurance (1988) [hereinafter Medical Testing and Health Insurance]. 
ing genetic testing. Market researchers project that U.S. genetic test sales will reach several hundred million dollars before the decade's end. ${ }^{39}$ The emergence of commercial interests in genetic test development provides powerful incentives to lower the cost of genetic testing, placing it within the reach of industry and insurance. If some insurers or employers begin to make increasingly more sophisticated genetic predictions, the pressure on others to utilize the same technology may become irresistible.

If the marketplace itself is the only restraint on this technology's proliferation, decreased prices and demonstrated cost-benefit advantages will make widespread adoption inevitable. The need for legal safeguards against genetic discrimination in employment and insurance is apparent.

\section{The Current Prevalence of Genetic Discrimination}

No systematic studies of genetic discrimination in employment and/or insurance settings have been undertaken. Professor Paul Billings and his colleagues did report twenty-nine cases of apparent genetic discrimination based upon responses to an advertisement. ${ }^{40}$ Other anecdotal reports of genetic discrimination have appeared in the media. ${ }^{41}$ The 1982 OTA survey reported that of the eighteen companies taking some action on the basis of genetic testing, seven of them transferred or dismissed the "at risk" employee. ${ }^{42}$ The 1989 OTA survey reported very few instances of negative personnel decisions resulting from genetic monitoring or screening. Only two Fortune 500 companies reported ever rejecting a job applicant or transferring an

${ }^{39}$ The commercial appeal of genetic testing is revealed in a staff background paper to the OTA 1990 Report, supra note 29. M. Hewitt \& N. Holtzman, The Commercial Development of Tests for Human Genetic Disorders (Feb. 1988) (unpublished manuscript). This paper reviews predictions of the market value of genetic tests from the following sources: ROBERT $S$. First, InC., Genetic Testing in the USA $1986-1990$ (1986) ( $\$ 550$ million by 1990$)$; Arthur $D$. Little Projects a $\$ 5.7$ Billion Clinical Diagnostic Market in 1990, Genetic Engineering News, Mar. 1987, at 13 ( $\$ 300$ - $\$ 500$ million by 1995); Disease Disposition Screening, Bromedical Bus. INT'L 230, 230-32 (1986) (U.S. current market value of genetic tests estimated at $\$ 210$ million); DNA Probes Nudge Monoclonals in the Race to Exploit the Medical Diagnostics Market, GENETIC ENGINEERING News, Sept. 1986, at 1, 12, 13, 21 ( $\$ 500$ million market value by 1993); Market for DNA Probe Tests for Genetic Diseases, Genetic Tech. News, Nov. 1986, at 6-7 (\$950 - $\$ 1000$ million market value by 1992). More recently, Business Week predicted a $\$ 200$ million-a-year market for genetic tests being actively sought after by prominent bio-technology companies. Carey, The Genetic Age, Bus. WEEK, May 28, 1990, at 68.

40 Billings, supra note 2, at 8.

41 See, e.g., MacDonald, Ethical Eye on Insurers' Genetic Tests, Daily Telegraph, July 15, 1990, at 9 (describing an engineer who "was refused health or life insurance because he had haemochromatosis - excessive absorption and storage of iron - despite having been treated and declared fit by his doctor").

42 OTA 1983 REPORT, supra note 29 , at 37. 
employee primarily or partly because of genetic test results. ${ }^{43}$

Reported cases of genetic discrimination support the idea that adverse decisions are often based upon mythologies and misconceptions rather than real cost or safety concerns. Adverse decisions are based on genetic status, rather than actual disability, lack of qualification or accurate forecasting of future impairment. A common misconception equates the presence of a genetic trait with actual disability, absent any demonstrated nexus between current impairment and inability to meet reasonable qualification standards. Genetic discrimination affects not only heterozygotes (unaffected carriers) and "at risk" individuals (those with a predisposition to disease), but also persons who are asymptomatic or have a minor form of the disease. For example, several cases of discrimination were reported involving heterozygotes of sickle cell ${ }^{44}$ or Gaucher Disease. ${ }^{45}$ These genetic traits ${ }^{46}$ may affect a future offspring, but not the carrier herself. Discrimination against an unaffected carrier is particularly pernicious because the condition is irrelevant to the person's current or future health status or abilities. The discrimination is based upon the mythology that a heterozygote has the disease or will develop it.

"At risk" persons have a propensity to develop genetic disease based upon a positive DNA test result or family history. 47 Persons "at risk" may be treated as though they are currently impaired with the most severe form of the disease, even though there is great variability in the onset and severity of symptoms. For example, discrimination against persons with the marker for Huntington disease has occurred in cases involving rejection by adoption agencies and rejection of life insurance coverage. ${ }^{48}$

Persons actually affected with genetic disease are often wrongly be-

\footnotetext{
43 OTA 1990 REPORT, supra note 29, at 182.

44 See Shapiro, Dangers of DNA: It Ain't Just Fingerprints, N.Y.L.J., Jan. 23, 1990, at 1 (quoting Dr. Phillip Bereano) (" "The Armed Forces for many years have followed a policy of excluding the carriers of sickle cell disease, despite the fact that these individuals are not themselves impaired. ... " "); see also Matthewman, Title VII and Genetic Testing: Can Your Genes Screen You Out of a Job?, 27 How. L.J. 1185, 1199 (1984); Raymann, Sickle Cell Trait and the Aviator, 50 Aviation Space \& Envtl. Med. 1170 (1979).

45 See, e.g., Billings, supra note 2, at 11 (man found to be an unaffected carrier of Gaucher Disease was denied a government job because he was told he was a " 'carrier, like [of] sickle cell.' ").

46 See T. Duster, supra note 12, at $41-42$ ("trait" is a term normally applied to carriers of autosomal dominant disorders; "the best known of these . . . are Tay-Sachs disease, betathalassemia, sickle cell anemia, and cystic fibrosis").

47 See Shaw, Genetic Gains Raise Fear of a New Kind of Bias, Philadelphia Inquirer, Nov. 23, 1990, at 1-A, col. 1 (describing the case of a Chicago woman, turned down for a job after her prospective employer learned that her mother was schizophrenic; employer feared schizophrenia was inherited).

48 Billings, supra note 2, at 13-14; Brownlee \& Silberner, supra note 34, at 57.
} 
lieved to have severe symptoms, even if their impairments are relatively minor. In the extreme case, discrimination has occurred against the "healthy ill," those who test positive for a hereditary condition but are asymptomatic. ${ }^{49}$ In other cases, persons are discriminated against because of a genetic condition despite the fact that the symptoms do not interfere with performance. Persons with Charcot-Marie-Tooth Disease (CMT), a hereditary motor-sensory neuropathy, ${ }^{50}$ have been rejected from life, accident or automobile insurance even though very mildly affected..$^{51}$ One case of discrimination occurred despite a favorable letter from the individual's personal physician and the absence of any record of past ill-health or accidents. ${ }^{52}$

Cost saving is the implicit goal in many cases of genetic discrimination. A decision to deny health or life insurance because of a diagnosis of hemochromatosis, ${ }^{53}$ or a positive fetal DNA test for cystic fibrosis, ${ }^{54}$ is based upon the belief that these individuals or their offspring could burden health care and other benefit plans. Whether cost alone can ever be a sufficient justification for genetic discrimination is a critical public policy question.

\section{LEGAL MECHANISMS TO REDRESS GENETIC DISCRIMINATION}

While discrimination based on individual status may be morally wrong, it is not necessarily unlawful. Congress and state legislatures have proscribed discrimination against classes based upon characteristics including race, gender, religion, national origin, age and disability. ${ }^{55}$ However, most jurisdictions do not have equivalent statutory safeguards to protect against inequitable treatment based on other immutable personal characteristics such as sexual orientation, height or appearance. The key to determining the lawfulness of genetic discrimination under existing statutes is whether classification based upon genetic characteristics is more akin to the categories of race, gender and

49 See, e.g., Billings, supra note 2, at 20-21 (reporting the case of a person with hereditary hemochromatosis who, despite the absence of symptoms, was consistently denied insurance); see also Brownlee \& Silberner, supra note 34, at 57 (quoting Dr. Neil Holtzman).

50 Griffin \& Cornblath, Peripheral Neuropathies, in The Principles and Practice of Medicine, supra note 22, at 1092, 1095-96 (weakness, particularly footdrop, foot deformity and hand weakness are the most severe manifestations of Charcot-Marie-Tooth disease (CMT))

51 Billings, supra note 2, at 10-11.

52 Id. at 10.

53 See MacDonald, supra note 41, at 9 . Hemochromatosis is characterized by an excessive absorption and storage of iron and can be controlled. See The Principles and Practice of Medicine, supra note 22, at 289, 862-63.

54 See Billings, supra note 2, at 18; see also supra note 25 for a description of this incident.

55 See infra notes 171-96 and accompanying text. 
disability, or the categories of sexual orientation, personality and intelligence. Certainly, genetic discrimination, which disproportionately burdens particular races, religions or genders, needs to be examined under relevant civil rights legislation. Before examining that fertile area of inquiry, this paper will discuss whether a genetic condition or trait should be regarded as a disability.

\section{A. The Applicability of Disability Law to Genetic Discrimination}

Three sources of disability law have emerged from federal, state and municipal legislatures: the Americans with Disabilities Act of 1990 and other federal disability legislation, ${ }^{56}$ state and municipal handicap laws, and genetic-specific laws. The Americans with Disabilities Act of 1990 (ADA) is the most sweeping civil rights measure since the Civil Rights Act of $1964 .^{57}$ The ADA, unlike its predecessor, the Rehabilitation Act of $1973,{ }^{58}$ extends antidiscrimination protection of persons with disabilities to private sector employment (Title I), public services (Title III), public accommodations (Title III) and telecommunications (Title IV).

State and municipal disability legislation are important supplements to federal law. All states have disability statutes, all but four of which prohibit discrimination in the private, as well as public sector. ${ }^{59}$ Courts have held that state disability statutes closely follow the federal civil rights approach and should be construed accordingly. ${ }^{60}$ State and local disability laws are typically enforced by a network of experienced human rights organizations that can be far more productive than courts in preventing and remedying discrimination. These administrative

56 Federal legislation provides protection to persons with disabilities in several areas. E.g., Education for All Handicapped Children Act of 1975 (EAHCA), Pub. L. No. 94-142, 89 Stat. 773 (codified as amended in scattered sections of 20 U.S.C.) (giving all school-aged children with disabilities the right to a free public education in the least restrictive environment appropriate to their needs) (note that in order to reflect progressive language Congress renamed EAHCA the Individuals with Disabilities Education Act, Act of Oct. 30, 1990, Pub. L. No. 101-476, 104 Stat. 1142); Fair Housing Amendments Act of 1988, Pub. L. No. 100-430, 102 Stat. 1619 (codified, among other places, at 42 U.S.C. $\$ \$ 3601-3614 a$ (Supp. 1990)).

57 Civil Rights Act of 1964, Pub. L. No. 88-352, 78 Stat. 241 (codified at 42 U.S.C. $\$ 1981$ (1988)).

58 The Rehabilitation Act of 1973, Pub. L. No. 93-1 12, 87 Stat. 355 (codified as amended at 29 U.S.C. $\$ \S 701-794$ (1988)), survives the subsequent enactment of the ADA, and continues to be the prime legislation affecting persons with disabilities working for the federal government. See 42 U.S.C.A. $\$ 12209$ (a), (b) (West Supp. 1990) (Coverage of Congress and the agencies of the Legislative Branch).

59 National Gay Rights Advocates, Protection Against Discrimination Under State Handicap Laws: A Fifty State Analysis (1989). See B. Bridgham \& M. Rowe, AIDS and Discrimination - A Review of State Laws that AfFect HIV Infections 1983-1988 (1989).

${ }^{60}$ See, e.g., Raytheon Co. v. Fair Employment \& Hous. Comm'n, 212 Cal. App. 3d 1242, 261 Cal Rptr. 197 (1989). 
agencies initiate targeted education and use reconciliation effectively. ${ }^{61}$ Many agencies report settling eighty percent or more of their cases through these less costly and less adversarial methods. ${ }^{62}$ Because of this existing regulatory network dedicated to education, factfinding and alternative forms of dispute resolution, state and local disability legislation will continue to be important sources of law to prevent and remedy genetic discrimination.

Reinforcing the importance of safeguarding persons from genetic discrimination, a few states and municipalities have enacted specific legislation. Some of these laws apply generally to hereditary disorders, ${ }^{63}$ but most are directed to particular traits such as sickle cell, TaySachs or Cooley's Anemia. ${ }^{64}$ Since most state and local legislatures have thus far refrained from enacting genetic-specific anti-discrimination legislation, ${ }^{65}$ the primary source of law continues to be disability law.

The legislative history of the ADA indicates that little attention was given to genetic discrimination. Congressman Steny Hoyer, the Floor Manager in the House, informed the Congressional Bioethics Advisory Committee that genetic discrimination was "not raised or discussed," and that it could not, therefore, be addressed by the Conference Committees. ${ }^{66}$ Congressman Hoyer recognized that genetic discrimination was "improper" and "very dangerous," but left it to the courts to determine whether it was covered under the ADA. ${ }^{67}$ Nevertheless, several Congressmen supported the argument that "the ADA will also benefit individuals who are identified through genetic tests as being carriers of a disease-associated gene." 68 These legislators referred to the history of genetic discrimination, particularly during the sickle cell

61 The ADA also encourages "the use of alternative means of dispute resolution, including settlement negotiations, conciliation, facilitation, mediation, factfinding, minitrials, and arbitration." 42 U.S.C.A. $\$ 12212$ (West Supp. 1990).

62 R. Steele, S. Karsten, B. Lorenz \& J. Ritter, Identification and Assessment of State and local Strategies to Prevent Discrimination (1989).

${ }^{69}$ E.g., Cal. Health \& Safety Code $\$ 150(f)$ (West 1990) ("'c]arriers of most deleterious genes should not be stigmatized and should not be discriminated against by any person").

64 E.g., 1990 N.Y. LAws 900 (persons with sickle cell trait and carriers of Tay-Sachs disease or Cooley's anemia may not be denied opportunities for employment unless their disorder would prevent them from performing the job).

65 Compare this restraint with the flood of HIV-specific anti-discrimination state legislation. See Gostin, The AIDS Litigation Project: A National Review of Court and Human Rights Commission Decisions, Part II: Discrimination, 263 J. A.M.A. 2086 (1990); Gostin, Public Health Strategies for Confronting AIDS: Legislative and Regulatory Policy in the United States, 261 J. A.M.A. 1621 (1989) [hereinafter Public Health Strategies for Confronting AIDS].

66 Letter from Rep. Steny Hoyer to Alexander Capron, Chairman of the Biomedical Ethics Advisory Committee 2 (Aug. 1, 1990) (on file with American Joumal of Law E Medicine).

67 Id.

68136 Cong. Rec. H4614, 4623 (daily ed. July 12, 1990) (statement of Rep. Hawkins). 
screening programs in the $1970 \mathrm{~s} .{ }^{69}$

\section{Defining a Disability}

Disability is defined broadly in the ADA to mean: (A) "a physical or mental impairment that substantially limits one or more of the major life activities ... (B) a record of such impairment, or (C) being regarded as having such an impairment."70 "Physical or mental impairment" includes the following: any physiological disorder or condition, disfigurement or anatomical loss affecting any of the major bodily systems, or any mental or psychological disorder such as mental retardation, mental illness or dementia. ${ }^{71}$

A person is disabled if he or she has a "record" of or is "regarded" as being disabled, or is perceived to be disabled, even if there is no actual incapacity. ${ }^{72} \mathrm{~A}$ "record" indicates that the person has a history of impairment, or has been misclassified as having an impairment. ${ }^{73}$ This provision is designed to protect persons who have recovered from a disability or disease which previously impaired their life activities. By including those who have a record of impairment, Congress acknowledged that people who have recovered from diseases such as cancer, or have diseases under control such as diabetes, face discrimination based upon prejudice and irrational fear. ${ }^{74}$

Those " 'regarded'" as being impaired include individuals who have a covered impairment, but do not have limitations in their major life functions and are treated as if they did have such limitations. ${ }^{75}$ This concept protects people who are discriminated against in the false be-

${ }^{69} \mathrm{Id}$. at H4624 (statement of Rep. Don Edwards); id. at 4626 (statement of Rep. Henry Waxman).

7042 U.S.C.A. $\$ 12102(2)$ (West Supp. 1990). "The term physical or mental impairment does not include simple physical characteristics, such as blue eyes or black hair. . . [nor does it include] environmental, cultural, and economic disadvantages" in and of themselves. S. ReP. No. 116, 101 st Cong., 1st Sess. 22 (1989). The question may arise as to why genetic traits for sickle cell or cystic fibrosis ought to be covered in the ADA, but not the genetic determinants for blue eyes or black hair. The reason is simply that Congress has designated disability, but not general personal characteristics, under civil rights. Id.

7142 U.S.C.A. $\$ 12102(2)$ (West Supp. 1990). The definition of disability in the ADA is comparable to the term "handicap" in older legislation. Rehabilitation Act of 1973, 29 U.S.C. $\S 706(7)(B)$ (1988); Fair Housing Amendments Act of 1988, 45 U.S.C. $\$ 3602$ (h) (Supp. 1990). Congress intended that regulations implementing the Rehabilitation Act and the Fair Housing Amendments Act apply to the term "disability" in the ADA. The use of the term "disability" instead of "handicap" represents currently acceptable terminology. See S. REP. No. 116, supra note 70, at 21.

72 See Southeastern Community College v. Davis, 442 U.S. 397, 406 (1979) (“[a]n otherwise qualified individual is one who is able to meet all of a program's requirements in spite of his handicap").

73 S. REP. No. 116, supra note 70, at 23.

${ }^{74} \mathrm{Id}$.

${ }^{75}$ Id. See School Bd. of Nassau County, Fla. v. Arline, 480 U.S. 273, 284 (1987). 
lief that they are disabled. This provision is particularly important for individuals who are perceived to have stigmatic conditions that are viewed negatively by society. It is society's reaction, rather than the disability itself, that deprives the person of equal enjoyment of rights and services.

\section{Current Genetic Disability}

Persons currently disabled by a genetic disease are undoubtedly covered under the ADA. The legislative history of the Act, as well as prior case law, make clear that disability is defined only according to the degree of impairment of life functions. No distinction can be drawn between genetic and other causes of disabilities. Congress and the courts have recognized disabilities of both genetic (Down syndrome, ${ }^{76}$ muscular dystrophy, ${ }^{77}$ cystic fibrosis ${ }^{78}$ ) and multifactorial (heart disease, schizophrenia, epilepsy, diabetes and arthritis) ${ }^{79}$ origin. The question for courts is limited to whether the person is currently disabled. How she came to be disabled is irrelevant.

In defining disability, the courts require a "substantial" limitation of one or more major life activities. A genetic condition which does not cause substantial impairment may not constitute a disability. ${ }^{80}$ If a person with neurofibromatosis, for example, has only mild pigmentation changes she may not be disabled, but if she suffers from gross disfigurement she most assuredly would be protected under the ADA. ${ }^{81}$ Citing the example of cosmetic disfigurement, the Supreme Court said that

76 See Bowen v. American Hosp. Ass'n, 476 U.S. 610, 648 (1986) (White, J., dissenting) (clearly characterizing Down syndrome as a protected handicap). The Senate Committee on Labor and Human Resources drew attention to a "New Jersey zoo keeper who refused to admit children with Downs Syndrome because he feared they would upset the chimpanzees." S. REP. No. 116, supra note 70 , at 7 .

77 S. REP. No. 116, supra note 70, at 22.

78 Id. ("a person with lung disease will have a substantial limitation in the major life activity of breathing"). See Gerben v. Holsclaw, 692 F. Supp. 557, 563 (E.D. Pa. 1988) (cystic fibrosis is "clearly" a handicap under the Rehabilitation Act of 1973); Department of Educ. v. Katherine D., 531 F. Supp. 517, 519 (D. Haw. 1982) (cystic fibrosis is a handicap under the Education for All Handicapped Children Act of 1975).

${ }^{79}$ S. REP. No. 116, supra note 70, at 7, 22, 24. The Arline court quoted Senator Mondale's discussion of a woman "crippled by arthritis," who was denied a job simply because college trustees thought " 'normal students shouldn't see her,' " not because she could not do the work. Arline, 480 U.S. at 283 (citing 118 Cong. Rec. 36761 (1972)). See Doe v. Region 13 Mental Health-Mental Retardation Comm'n, 704 F.2d 1402 (5th Cir. 1983) (mental illness qualifies as a handicap under the Rehabilitation Act of 1973).

${ }^{80}$ E.g. , Arline, 480 U.S. at 273. Persons with minor or trivial impairments, such as a simple infected finger, are not disabled within the meaning of the Act. H.R. REP. No. 485, 101 st Cong., 2d Sess. pt. 2, at 152, reprinted in 1990 U.S. Code Cong. \& Admin. News 426, 435. However, if a defendant discriminates because she regards or perceives the genetic condition as more serious than it actually is, the person is protected under the third prong of the definition. See supra text accompanying note 71.

${ }^{81}$ Cf. S. REP. No. 116, supra note 70, at 24 (citing the example of a severe burn victim as a 
Congress was just as concerned about the effects of impairment on others as it was about its effects on afflicted individuals. ${ }^{82}$

\section{Future or Predicted Disability (presymptomatic)}

Genetic diagnosis or prognosis creates a new category of individuals who are asymptomatic but predicted to develop disease in the future. These individuals are sometimes referred to as the "healthy ill" or "at risk." 83 The number of people currently in this category is small since the technology is new and has only been applied to relatively rare diseases such as Huntington chorea. Progress in DNA technology will undoubtedly increase the range of diseases that can be detected before symptoms appear, and thus increase such categorization.

Can a person who is currently healthy but predicted to become ill be classified as "disabled" within the meaning of the ADA? Law, ethics and public policy suggest that such a person should receive the same protection as the currently disabled. The ADA expressly protects not only individuals who are actually disabled but those who are "regarded" as or perceived to be disabled. ${ }^{84}$ The law, therefore, does not objectively measure actual abilities or disabilities of the person. Rather, it judges disability through the subjective perceptions, prejudices and stereotypes as expressed by the source of the discrimination. Those who discriminate because of subjective and uncertain predictions of future impairment foster harmful stereotypes because the person is currently healthy and capable of meeting all job, benefit or service criteria. No sound judgment can be made regarding whether, when and to what extent the person will lose capabilities or whether reasonable accommodation could be provided. It would be inequitable for a defendant who intended to discriminate on the basis of disability to successfully raise the defense that the person was not currently disabled. A narrow construction of the terms " 'regarded' to be disabled" would yield an anomalous result. Persons with genetic conditions would be required to wait until they actually develop symptoms before becoming eligible for protection.

Congressional intent to include future disability within the scope

disabled person under the ADA). Technically, the effects of one's disfigurement on others could be classified under the third prong of the definition. See id.

82 Arline, 480 U.S. at 282 . While the Arline court was concentrating on infectious disease, its conclusion is equally applicable to genetic discrimination: "It would be unfair to allow an employer to seize upon the distinction between the effects of the disease on others and the effects of a disease on a patient, and use that distinction to justify discriminatory treatment." Id. at 282.

${ }^{83}$ See Human Genetics Committee of the Council for Responsible Genetics, Position Paper on Genetic Discrimination, Genewatch, May 1990, at 3. See also supra notes 47-49 and accompanying text.

8442 U.S.C.A. $\$ 12102(2)(c)$ (West Supp. 1990). 
of the ADA is reflected in the Act's legislative history and is consistent with prior case law. ${ }^{85}$ During the Conference Report debate on the ADA, Congressman Hawkins opined that persons who are genetically at risk "may not be discriminated against simply because they may not be qualified for a job sometime in the future. The determination as to whether an individual is qualified must take place at the time of the employment decision, and may not be based on speculation regarding the future." 86 Several Congressmen concurred, indicating that persons with future propensities toward disability are "regarded" as disabled. ${ }^{87}$

Case law concerning the federal Rehabilitation Act and state disability statutes also suggests that it is unlawful to discriminate on the basis of future disability. ${ }^{88}$ One court observed that it would be "ironic and insidious" if current disabilities were protected but the same protection were denied to those whom employers perceive to be predisposed to future disability. ${ }^{89}$ The New York Court of Appeals held that obesity is a handicap even though it causes no current disability. The court aptly observed that "disabilities, particularly resulting from disease, often develop gradually . . . An employer cannot deny employment simply because the condition has been detected before it has actually begun to produce deleterious effects."90 An employer also may not point to future safety risks as grounds for dismissal. ${ }^{91}$

The analogy of asymptomatic HIV infection is helpful in ascertaining a court's likely position on persons at risk for genetic disease. A positive test for HIV infection is a powerful predictor of future disease and disability. In 1986, the Justice Department concluded that while the disabling effects of AIDS may constitute a handicap, pure asymptomatic infection did not. ${ }^{92}$ The original Justice Department position

85 See supra note 75 and accompanying text.

86136 Cong. Rec. H4614, 4623 (daily ed. July 12, 1990).

87 Id. at 4626 (statement of Rep. Waxman). See also id. at 4624 (statement of Rep. Edwards).

88 See Neeld v. American Hockey League, 439 F. Supp. 459 (W.D.N.Y. 1977) (concern for future harm to player with one eye); Kimmel v. Crowley Maritime Corp., 23 Wash. App. 78, 596 P.2d 1069 (1979) (knee injuries suggested future harm); Dairy Equip. Co. v. Department of Indus., 95 Wis. 2d 319, 290 N.W.2d 330 (1980) (employer feared an exacerbated future injury from a fall because employee had only one kidney). But see Burgess v. Joseph Schlitz Brewery Co., 298 N.C. 520, 259 S.E.2d 248 (1979) (disability refers to present, non-correctable loss of vision, not potentially disabling conditions, so that correctable glaucoma was not a handicap under the state statute).

89 Dairy Equip. Co., 95 Wis. 2d at 331, 290 N.W.2d at 335 (employee who had only one kidney was "handicapped" within the meaning of the state Fair Employment Act).

90 State Div. of Hum. Rts. v. Xerox Corp., 65 N.Y.2d 213, 219,480 N.E.2d 695, 698, 491 N.Y.S.2d 106, 109 (1985).

91 See Kimmel, 23 Wash. App. at 78, 596 P.2d at 1069 (knee injury that might pose future safety risk at sea).

92 Opinion of Charles J. Cooper, Assistant Attorney General, Office of Legal Counsel, for 
has been thoroughly repudiated by Congress and the courts. ${ }^{93}$ Both

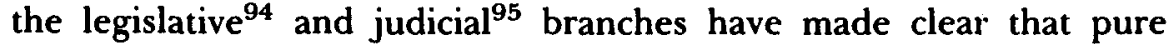
asymptomatic infection is protected under disability law.

It is difficult to distinguish between a predictive test for AIDS and one for Huntington disease. In both cases there are no current symptoms, the predictive values of the tests are strong, and onset and severity are uncertain. Employers might argue that persons who test positive for HIV have a current infection manifesting a clear disease process, while persons testing positive for Huntington disease do not. This is not a convincing argument. A defect in a specific chromosome can be identified as the beginning of a genetic disease process in the same way as infection is identified as the beginning of a contagious disease process. Public policy would be skewed if it left individuals unprotected while free of symptoms and protected them only after they developed symptoms. ${ }^{96}$ Courts are unlikely to accept this construction of the ADA.

\section{Genetic Carriers}

Carriers of recessive genetic diseases such as hemoglobin disorders (sickle cell and thalassemia) and Tay-Sachs have only one gene that influences the disease, whereas two genes are required in order to manifest the disease. A carrier will not develop symptoms, but her offspring may inherit the disease if her partner is also a carrier. Employers, insurers or health care providers may discriminate against carriers because of a fundamental misconception that a recessive gene might affect a person's own health or capabilities. ${ }^{97}$

The ADA's prohibition of discrimination based upon a perception of disability applies to those who falsely assume that carriers are, or will become, disabled. ${ }^{98}$ The primary purpose of disability law is to overcome such irrational fears and beliefs. The courts have made clear, for

Ronald E. Robertson, General Counsel, Department of Health and Human Services, June 23, 1986.

93 The Justice Department reversed its opinion in 1988. Memorandum for Arthur B. Calvahouse, Jr., Counsel to the President, from Douglas W. Kamiec, Acting Assistant Attorney General, Office of Legal Counsel, re Application of Section 504 of the Rehabilitation Act to HIV-Infected Individuals, Sept. 27, 1988.

94 See, e.g., Civil Rights Restoration Act of 1987, Pub. L. No. 100-259, 102 Stat. $28 \S 9$ (codified at 29 U.S.C.A. $\$ 706(8)(C)$ (West Supp. 1990)).

95 See, e.g., Doe v. Centinela Hosp., 57 U.S.L.W. 2034 (C.D. Cal. 1988) (asymptomatic carrier of AIDS virus protected under Rehabilitation Act).

96 See Genetic Testing and the Americans with Disabilities Act, fact sheet accompanying letter from Alexander Capron, Edmund Pelligrino and Robert Mullan Cook-Deegan to Senator Tom Harkin (June 25, 1990) (on file with American Joumal of Law E Medicine).

97 See supra notes 44.45 and accompanying text for examples of discrinination against hrterozygotes.

98 See supra note 75 and accompanying text. 
example, that an unfounded fear of contracting an infectious disease is not tolerated under the law. ${ }^{99}$ The case law shows a consensus that employment decisions must be based upon reasonable medical judgments showing that the disability prevents the individual from meeting legitimate performance criteria. ${ }^{100}$

\section{Multifactorial Diseases and Environmental Factors}

The social impact of genetic diagnosis and prognosis is felt strongly in the occupational setting. The identification of persons who are hypersusceptible to occupational disease provides a possible health justification for employment discrimination. These persons are protected under the ADA provided the employer's decision is based on a perception that the person is, or will become, disabled. ${ }^{101}$ A federal district court, for example, held that a person who is unusually sensitive to tobacco smoke is handicapped under the federal Rehabilitation Act of 1973. ${ }^{102}$ The court reasoned that this hypersensitivity limited one of the employee's major life activities, his capacity to work in an environment which is not completely smoke-free. ${ }^{103}$ Similarly, a sportsperson may be disabled if she has a weak heart ${ }^{104}$ or poor eyesight, ${ }^{105}$ both of which make her susceptible to future harm or injury, and a firefighter may be disabled if the stresses of the job would provoke a sickle cell crisis. ${ }^{106}$

The promise of the ADA is to protect individuals who are, or are perceived to be, disabled in the past, present or potentially in the future. It would be a betrayal of that promise if the law "did not equally protect individuals who are not, and indeed, may never be disabled, but whose predictive genetic tests cast a shadow over their own future health or that of their children."107

99 See School Bd. of Nassau County, Fla. v. Arline, 480 U.S. 279, 284 (1987) ("society's accumulated myths and fears about disability and disease are as handicapping as are the physical limitations that flow from actual impairment").

100 See Burris, Rationality Review and the Politics of Public Health, 34 VILL. L. REv. 933, 978-81 (1989); Gostin, The Future of Public Health Law, 12 AM. J.L. \& MEd. 461, 467 (1987).

101 See supra text accompanying note 75 (discussing individuals "regarded" as disabled).

102 Vickers v. Veterans Admin., 549 F. Supp. 85 (W.D. Wash. 1982).

103 Id. at 87.

104 Dodd, Who Decides Health Risk is Too High?, USA Today, Oct. 5, 1990, at C1, col. 1.

105 See Neeld v. American Hockey League, 439 F. Supp. 459 (W.D.N.Y. 1977) (denial of plaintiff with sight in only one eye an opportunity to play professional hockey would result in irreparable harm).

106 See, e.g., Peoples v. City of Salina, Kan., No. 88-4280-S, 1990 U.S. Dist. LEXIS 4070 (D. Kan. March 20, 1990). Employers, however, can take action if the person's condition renders him unqualified for the job or would pose a direct threat to others in the workplace. 42 U.S.C.A. \$12111(3) (West Supp. 1990).

107 Letter from Nachama L. Wilker \& Ruth Hubbard, Council for Responsible Genetics, to Rep. Steny Hoyer (June 27, 1990) (on file with American Joumal of Law E' Medicine). 


\section{B. Employment Discrimination Under Disability Law}

1. "Qualification Standards," Including "Direct Threat"

The anti-discrimination principle in the ADA applies only to "qualified individuals." 108 A "qualified" person must be capable of meeting all of the performance or eligibility criteria for the particular position, service or benefit. ${ }^{109}$ ADA qualification standards may include a requirement that an individual not pose a "direct threat" to health or safety in the workplace. ${ }^{110}$ There is, moreover, an affirmative obligation to provide "reasonable accommodations" 111 or "reasonable modifications" 112 if they would enable the person to meet performance or eligibility criteria. Employers are not required to provide reasonable accommodations if such provision would pose an undue hardship on the operation of the business. ${ }^{13}$

How do such terms as "qualified," "direct threat," "reasonable accommodation" and "undue hardship" apply to discrimination based upon a genetic prediction of future disability of the employee or her offspring? Qualification standards are measured against current skills and performance. The fact that a person may become unqualified sometime in the future does not justify discrimination. As noted by Representative Waxman and others throughout the legislative process on the ADA, "[t]he determination as to whether a person is qualified must be made, however, at the time of the particular employment decision - of hiring, firing, promotion, and so forth - and may not be based upon speculation and predictions regarding the person's ability to be qualified for the job in the future." 114

Congress, however, was acutely aware of the potential risks disabled persons pose to the health and safety of others in the workplace. ${ }^{115}$ Although the "direct threat" criterion was limited to persons

10842 U.S.C.A. $\$ \S 12112$ (a), 12132 (West Supp. 1990).

109 Title I requires qualification standards, employment tests, or other selection criteria to be "job-related" and "consistent with business necessity." Id. at \$12112(b)(b). Title II requires the disabled person to meet the "essential eligibility requirements for the receipt of services or the participation in programs or activities." Id. at $\$ 12131$ (2).

110 Id. at $\$ 12113$ (b). "Direct threat" means "a significant risk to the health or safety of others that cannot be eliminated by reasonable accommodation." Id. at $\$ 12111(3)$.

111 ld. at $\$ 12112(\mathrm{~b})(5)$.

112 Id. at $\$ 12131(2)$.

119 Id. at $\$ 12112$ (b)(5)(A). See Southeastern Community College v. Davis, 442 U.S. 397, 410,412 (1979) (this exception requires "fundamental alteration in the nature of the program" or "undue financial and administrative burdens"). "Undue hardship" is carefully defined as "requiring significant difficulty or expense" when considered in light of many enumerated factors. 42 U.S.C.A. \$ $12111(10)(A)$.

114136 Cong. Rec. H4614, 4626 (daily ed. July 12, 1990) (statement of Rep. Waxman). See also id. at 4614 (statement of Rep. Hawkins).

115 See, e.g., Joint Explanatory Statement of the Committee of Conference para. 2 ("direct threat") and para. 13 ("health and safety"); S. REP. No. 116, supra note 70, at 27. 
with contagious disease in the Senate Bill, it was extended in Conference to all individuals with disabilities. ${ }^{116}$ The ADA does not override pre-existing medical standards or requirements for workplace safety mandated by federal, state or local law. ${ }^{117}$ Employers may also establish legitimate medical standards. ${ }^{18}$

Since occupational health and safety concerns are incorporated within qualification standards, they must primarily be determined by actual workplace risks and not speculation about risks which are theoretical, remote or distant. ${ }^{119}$ The courts, however, are likely to uphold decisions to protect employees from foreseeable risks in the immediate future, particularly for safety or security sensitive positions. ${ }^{120}$ For example, clear medical evidence demonstrating a likelihood of harm or injury may disqualify a person from an inherently risky position such as an airline pilot, a police officer or a firefighter. ${ }^{121}$

The ADA's explicit language refers to significant risks to the health or safety of other individuals in the workplace. ${ }^{122}$ Thus, current or foreseeable health and safety risks define the parameters of genetic discrimination. Occupational risks must be significant. The determination of significant risk must be based upon scientific evidence. ${ }^{123}$ Disability law has been thoughtfully crafted to replace reflexive actions based upon irrational fears, speculation, stereotypes or pernicious mythologies, with carefully reasoned judgments based upon well established scientific information. ${ }^{124}$ Significant risk must therefore be determined on a case by case basis, and not under any type of blanket rule, generalization about a class of disabled persons, or assumptions about the nature of disease. This requires a fact-specific individualized inquiry such that a "well-informed judgment grounded in a careful and openminded weighing of risks and alternatives" results. ${ }^{125}$ A specific deter-

116 H.R. REP. No. 596, supra note 80, at pt. 3, 11, reprinted in 1989 U.S. Code ConG. \& Admin. News at 566. In the House, the standard of "direct threat" was extended by the Judiciary Committee to all individuals with disabilities, and not simply those with contagious diseases or infections. H.R. REP. No. 485, supra note 80 , pt. 3, at 34, reprinted in 1990 U.S. Code Cong. \& Admin. News at 457.

117 Joint Explanatory Statement of the Committee of Conference, para. 10 ("pre-employment inquiries").

11842 U.S.C.A. $\$ \S 12112$ (c)(3), 12113 (b) (West Supp. 1990).

119 Id. at $\$ 12113$ (b) ("Qualification standards").

120 See School Bd. of Nassau County, Fla. v. Arline, 480 U.S. 273, 285 (1987).

121 See Joint Explanatory Statement of the Committee of Conference, para. 10.

12242 U.S.C.A. $\$ \S 12111(3), 12113($ b).

123 See, e.g., H.R. REP. No. 485, supra note 80, at pt. 2, 56-57, reprinted in 1990 U.S. CoDE Conc. \& Admin. News, at 339.

124 The legislative record is replete with statements rejecting decision-making based upon ignorance, misconceptions and patronizing attitudes. See, e.g., id., pt. 2, at 7, 121; id., pt. 3, at 52, 153; id., pt. 4, at 38; S. Rep. No. 116, supra note 70, at 27.

125 Hall v. United States Postal Serv., 857 F.2d 1073, 1079 (6th Cir. 1988) (quoting School Bd. of Nassau County, Fla. v. Arline, 772 F.2d 759, 764-65 (1 1 th Cir. 1985)). See also 
mination must be made that a person with a genetic pre-disposition will develop symptoms in the immediate future that represent a real threat to health or safety in the workplace.

The language of the ADA refers to the risk to "other individuals" in the "workplace." Strictly construing the Act, courts might disregard risks to the health of the disabled person. Thus, disabled persons may argue that they cannot be discriminated against merely because they are hypersusceptible to workplace toxins or because they pose a safety risk to themselves. However, courts adopting a broader view of the Act may disqualify disabled persons if occupational exposure poses a significant and immediate threat to their health. Courts are not likely to overturn employers' decisions to terminate employees to avoid an immediate sickle cell crisis ${ }^{126}$ or to avoid a likely heart attack or a physical injury to a vulnerable sportsperson. ${ }^{127}$ Whether or not a well documented and serious longer-term risk of cancer would justify discrimination remains to be decided. ${ }^{128}$ The courts, however, would comply with the letter and spirit of the ADA if they did not allow discrimination based upon cumulative exposure to workplace toxins over many years. Such discrimination could motivate widespread genetic discrimination. As suggested earlier, this would also provide an excuse for employers to weed out hypersusceptible workers rather than reduce overall toxic levels. ${ }^{29}$

The reference in the ADA to the risk to others in the "workplace" raises the question of whether employers can discriminate based upon risks to future offspring. The language would not permit discrimination against genetic carriers since the risk to the fetus does not arise from the workplace environment. Risks of teratogenicity to the employee or congenital risks to the fetus in the womb stemming from occupational exposure may present closer jurisprudential and ethical questions. This form of discrimination is more likely to be directed against women rather than disabled persons, so it will be discussed under gender discrimination below. ${ }^{130}$

Mantolete v. Bolger, 767 F.2d 1416 (9th Cir. 1985); Strathe v. Department of Transp., 716 F.2d 227 (3d Cir. 1983).

126 See Peoples v. City of Salina, Kan., No. 88-4280-S, 1990 U.S. Dist. LEXIS 4070 (D. Kan. Mar. 20, 1990).

127 See supra notes 104-05 and accompanying text.

128 See Jackson v. Johns-Manville Sales Corp., 781 F.2d 394 (5th Cir. 1986) (whether an individual exposed to asbestos but not currently symptomatic can recover today for the likelihood of future cancer).

129 See supra text accompanying notes 101-06.

130 Fetal protection policies involve excluding women from the workplace because of potential harms to the fetus. This sets up an express class based upon gender. See, e.g., International Union, UAW v. Johnson Controls, Inc., 886 F.2d 871 (7th Cir. 1989), rev'd, 1991 US LEXIS 1715. 


\section{2. "Reasonable Accommodations" and "Undue Hardship"}

To enable a disabled person to meet qualification standards, the employer has an affirmative obligation to provide reasonable accommodations, including the reduction of significant risks to health or safety. ${ }^{131}$ While the ADA primarily addresses physical barriers to access, it also requires that workplace environments be "usable" by individuals with disabilities. ${ }^{132}$. This could include reducing environmental hazards to which the disabled person is hypersusceptible. One federal district court assumed that this would include marked reductions in tobacco smoke to accommodate an employee who was hypersensitive, but did not require providing a smoke-free environment. ${ }^{133}$

The ADA requires reasonable accommodations unless they would impose an "undue hardship" on the operation of the business. ${ }^{134} \mathrm{Un}$ due hardship means an action requiring significant difficulty or expense when considered against such factors as the nature and cost of the accommodation and the overall financial resources and size of the business. ${ }^{185}$ Employers do not have to provide accommodations that would fundamentally alter the nature of the industry. ${ }^{136}$ For example, a company need not stop producing batteries to eliminate lead levels. ${ }^{137} \mathrm{Em}$ ployers that can improve workplace environments without undue financial burden may be required to do so.

\section{Pre-employment Genetic Testing and Prognosis}

The ADA's prohibition of discrimination against persons with disabilities also applies to medical examinations and inquiries. ${ }^{188}$ Historically, employers gathered information concerning the applicant's physical and mental condition through application forms, interviews and medical examinations. ${ }^{139}$ This information was often used to exclude disabled persons from employment, particularly applicants with hidden disabilities such as epilepsy, emotional illness, cancer or HIV infection. ${ }^{140}$ The employer's ability to systematically obtain and use

13142 U.S.C.A. §§ $12111(3),(9), 12112(b)(5)$ (West Supp. 1990).

132 Id. at $\$ 12111(9)(\mathrm{A})$.

133 Vickers v. Veterans Admin., 549 F. Supp. 85 (W.D. Wash. 1982).

13442 U.S.C.A. $\$ 12111$ (10) (West Supp. 1990).

195 Id. at $\$ 12111(10)(B)$. Congress explicitly rejected the implication of the Supreme Court in TWA v. Hardison, 432 U.S. 63 (1977), that an employer need not expend more than a de minimis amount for the accommodations. S. REP. No. 116, supra note 70, at 36 .

136 S. REP. No. 116, supra note 70, at 35.

137 See, e.g. International Union, UAW v. Johnson Controls, 886 F.2d 871 (7th Cir. 1989), rev'd, 1991 US LEXIS 1715; see also supra notes 128-29 and accompanying text.

13842 U.S.C.A. $\$ 12112$ (b)(7), (8) (West Supp. 1990).

139 See Rothstein, supra note 15, at 1409-21.

140 See S. ReP. No. 116, supra note 70, at 39. 
medical information to predict hidden conditions expands with the development of genetic testing and prognosis.

Discrimination against persons with hidden disabilities has been unlawful since the Rehabilitation Act of 1973. Enforcement, however, has been exceedingly difficult, since an employer need not disclose that the person's medical condition was the prime reason for the failure to hire. So long as employers were able to conduct extensive medical examinations before offering a job, they could effectively hide the true reason for the employment decision.

The ADA prohibits employers from conducting pre-offer medical inquiries. ${ }^{141}$ Section 12112(c)(4)(a) prohibits employers from conducting medical examinations or inquiries to determine a job applicant's disabilities. Pre-employment inquiries must be limited to assessing the applicant's ability to perform job-related functions. ${ }^{142}$ Thus, employers may not require job applicants to undergo extensive medical examinations and screenings, including diagnosis and prognosis for genetic traits or conditions. This will strictly limit the employer's ability to obtain information about a person's current and future illness, diseases or genetic pre-dispositions before a job is offered.

The ADA permits an employer to require an entrance examination only after an offer of employment has been made, provided all entering employees are subjected to the same examination and the medical information is kept strictly confidential. ${ }^{143}$ Employers are also limited in their right to conduct medical examinations or inquiries after a person is hired. The employer cannot compel an employee to take a medical examination or inquire as to whether the employee is disabled unless the examination or inquiry is job related and consistent with business necessity. ${ }^{144}$ Congress, in enacting the ADA, recognized that " $[\mathrm{a}] \mathrm{n}$ inquiry or medical examination that is not job-related serves no legitimate employer purpose, but simply serves to stigmatize the persons with a disability." 145 The ADA will significantly impede the growing use of medical testing and information gathering used by employers across America, thus transforming the way the business community makes hiring decisions.

14142 U.S.C.A. $\$ 12112$ (c)(2)(A) (West Supp. 1990). For the purposes of the ADA, drug testing is not considered a medical examination, and employers are not prohibited from taking action against a person who is currently engaging in the illegal use of drugs. Id. at $\S 12114(d)(1)$.

142 Id. at $\$ 12112(\mathrm{c})(1),(4)(\mathrm{A})$.

143 Id. at $\$ 12112(\mathrm{c})(3)(\mathrm{A})-(\mathrm{C})$.

${ }^{144} I d$. at $\$ 12112(\mathrm{c})(4)(\mathrm{A})$.

145 S. REP. No. 116, supra note 70, at 39. 


\section{Employer Costs: Health, Disability, Life and Other Insurance Benefits ${ }^{146}$}

Employers utilizing genetic testing cite cost benefit and greater productivity as the main reasons. ${ }^{147}$ Employers' costs for health care and other benefits have risen substantially in recent years. ${ }^{148}$ These costs are borne directly by employers with larger work forces, many of whom tend to be self-insurers or have experience rating. Alternatively, increased benefits costs are passed on from insurance companies to employers in the form of higher premiums. ${ }^{149}$

Some astute commentators on disability law give considerable credence to employer decisions not to hire persons with current or future disabilities based upon probable costs to health, disability, life and other insurance benefits. "If a worker will become ill, and if the employer will be responsible for the medical costs as well as the output costs of the worker's absence, then the predicted illness is nothing but a future dollar cost that the employer must consider and discount."150

The legislative and judicial consensus contradicts that of industry, holding financial burdens on employee benefit programs insufficient to

146 The Employee Retirement Income Security Act of 1974 (ERISA) may provide an additional source of law to remedy discrimination based purely on cost factors. 29 U.S.C. $\$ \S 1001-1461$ (1988). Section 510 of ERISA makes it unlawful for an employer to "discriminate against a participant or beneficiary for exercising any right to which he is entitled under the provisions of any employer benefit plan. . . or any right to which such participant may become entitled under [such benefit] . . p plan." Id. at $\$ 1140$.

ERISA allows a participant or beneficiary to bring a civil action in order to recover benefits due him or clarify or enforce his rights under the plan. Id. at $\$ 1132(\mathrm{a})(1)(\mathrm{B})$. The term participant refers to an "employee or former employee of an employer, or any member or former member of an employee organization, who is or may become eligible to receive benefits." $I d$. at $\S 1002(7)$. A beneficiary is "a person designated by a participant, or by the terms of an employee benefit plan." Id. at $\$ 1002(8)$. Apparently, one can only become a participant and thus eligible (through the automatic operation of a benefit plan or through self-selection) to designate beneficiaries, once one is hired. Indeed, courts have thus far restricted entitlement under ERISA to current or discharged employees. See Liebman, supra note 1 , at 87-88. Thus, ERISA may provide a remedy for persons with genetic conditions or pre-dispositions once they are hired.

While ERISA does not require employers to provide benefit plans at all, it does prohibit employers from discriminating against employees because they may disproportionately burden a benefit plan now or in the future. See Folz v. Marriot Corp., 594 F. Supp. 1007, 1014-15 (W.D. Mo. 1984) (discharge of an employee after revelation to employer that the employee suffered from multiple sclerosis and where no complaints of employee's job performance existed, violated ERISA); see also Vogel, Containing Medical and Disability Costs by Cutting Unhealthy Employees: Does Section 510 of ERISA Provide a Remedy?, 62 Notre Dame L. REV. 1024, 1028-29, 1029 n.29 (1987).

147 OTA 1990 RePORT, supra note 29, at 181-82.

148 See generally Liebman, supra note 1, at 84-85; Vogel, supra note 146, at 1024 \& n.1, 1029-39 (1987).

149 See Vogel, supra note 146, at 1028-29.

150 Liebman, supra note 1 , at 82. 
justify discrimination. ${ }^{151}$ The Senate Labor and Human Resources Committee echoed this theme throughout the legislative process: "an employer may not refuse to hire an individual because of fears regarding increased insurance costs attendant on hiring the individual either because of increased costs to be incurred because of that individual's health needs or because of the health needs of that individual's family."152

Disability law is concerned only with the relationship between a person's disability and her ability to perform the job she seeks. The fact that the person may have an undesirable impact on disability, life or health insurance programs is irrelevant. ${ }^{153}$ The courts have also rejected as justifications for discrimination a wide array of business or economic interests such as picketing the establishment, ${ }^{154}$ a threat of violence against workers, ${ }^{155}$ adverse publicity ${ }^{156}$ and loss of clientele. ${ }^{157}$ Courts reject cost as an excuse for discrimination because antidiscrimination has a higher social value than strictly economic business interests. Allowing such cost considerations to prevail could erode the protections currently conferred by disability law. ${ }^{158}$

People with genetic traits, conditions or pre-dispositions should not be denied a job or promotion based upon their perceived or future disabilities, and they should have equal access to health and other insurance coverage provided to all employees. Employers, however, may circumvent anti-discrimination principles when they are self-insurers. ${ }^{159}$ In such cases they may be judged as if they were underwriting risks, rather than making employment decisions. Agencies required to promulgate regulations under the ADA should carefully consider the interaction of unlawful employment decisions with lawful underwriting decisions, to ensure that the latter are not used to circumvent the overriding anti-discrimination principles under the Act.

151 See generally S. REP. No. 116, supra note 70.

152136 Conc. Rec. H4614, 4627 (daily ed. July 13, 1990) (statement of Rep. Waxman).

153 See State Div. of Hum. Ris. v. Xerox Corp., 65 N.Y.2d 213, 219,480 N.E.2d 695, 697.

98, 491 N.Y.S.2d 106, 108, (1985); Shawn v. Legs Co. Partnership, Sup. Ct. N.Y. Cty., AIDS

Lit. Rptr., March 10, 1989.

154 Mosby v. Joe's Westlake Restaurant, No. 86-5045 (Cal, Super. Ct., San Francisco County).

155 Cronan v. New Eng. Tel., 41 Fair Empl. Prac. Cas. (BNA) 1273 (Mass. 1986).

156 Shannon v. Charter Red Hosp., Admin. Complaint, Dallas, Tex., April 28, 1986.

157 Shawn, Sup. Ct. NY, AIDS Lit. Rptr., March 10, 1989.

158 Representative Owens stated: "Allowing the fact of such increased costs to justify employment discrimination would effectively gut the protections of the ADA for individuals with disabilities." 136 Cong. REc. H4614, 4623 (daily ed. July 13, 1990).

159 ERISA pre-empts state laws that "relate to any employee benefit plans," except state laws regulating insurance. 29 U.S.C. $\$ 1144$ (a), (b)(2) (1988). Employers who self-insure can avoid these state laws. See Vogel, supra note 146 , at 1028 \& n.24. 


\section{Insurance Discrimination Under Disability Law}

Congress intended to afford to insurers, employers and health care providers the same opportunities to design and administer insurance products and benefit plans in a manner that is consistent with the basic principles of underwriting, classifying and administering risks they would enjoy in the absence of the ADA. ${ }^{160}$ Thus, insurers may continue to sell to and underwrite individuals applying for life, health or other insurance; ${ }^{161}$ and employers and their agents may establish and observe the terms of employee benefit plans based upon sound actuarial data. ${ }^{162}$

It is, therefore, apparent that the ADA does not restrict insurers, health care providers or other benefit plan administrators from carrying on their normal underwriting activities. This includes the use of pre-existing condition clauses in health insurance contracts, the placing of caps or other limits on coverage for certain procedures or treatments or the charging of a higher premium to persons with higher risks. ${ }^{163}$

The adverse impact of underwriting for persons with genetic predispositions is significant. If insurers have actuarial data demonstrating a likelihood of future illness, they can limit coverage. More worrisome would be a decision by an insurer to view a genetic predisposition as a pre-existing condition. The greater genetic tests' predictive value, the more likely it is that insurers will regard the condition as uninsurable or pre-existing. This process is illuminated by the reaction of insurance

160 H.R. REP. No. 485, supra note 80 , pt. 2, at 136-38, reprinted in 1990 U.S. Code CoNG. \& Admin. News, at 419-21.

16142 U.S.C. $\$ 12201$ (c) (West Supp. 1990).

162 The Employment Retirement Income Security Act (ERISA) regulates employee benefits (including self-insured plans), effectively preempting the states, and specifically leaves insurance regulation to the states. Metropolitan Life Ins. v. Massachusetts, 471 U.S. 724 (1985). ERISA's exemption of self-insured plans from state insurance regulation is not affected by the ADA. 42 U.S.C. $\$ 12201$ (c). See, e.g., H.R. REP. No. 485, supra note 80, pt. 3, at 137, reprinted in 1990 U.S. Code Cong. \& ADMIN. NEws, at 420 ("Concerns had been raised that [portions of the ADA] could be interpreted as affection [sic] the preemption provision of ERISA. No such implication is intended."). The problem with ERISA's preemption provision is that self-insured plans cannot be required by states to provide certain benefits or to contribute to risk pools. Since an estimated $60 \%$ of all covered workers are under self-insured plans, a significant limitation is placed on the states that seek to rectify inequitable coverage. MED1cal Testing and Health Insurance, supra note 38, at 114.

163 See, e.g., S. REP. No. 116, supra note 70, at 29 ("The ADA does not, however, affect pre-existing condition clauses included in insurance policies offered by employers .... so long as such clauses are not used as subterfuge to evade the purposes of this legislation."). Nor can employee benefit plans be found to violate the ADA under impact of every person with a disability, for example, additional sick leave or medical coverage. "In sum, [ $\S 12201(\mathrm{c})$ ] is intended to afford to insurers and employers the same opportunities they would enjoy in the absence of this legislation to design and administer insurance products and benefit plans in a manner that is consistent with basic principles of insurance risk classification." H.R. ReP. No. 485, supra note 80 , pt. 2, at 137, reprinted in 1990 U.S. CODE CoNG. \& Admin. News, at 420-21. See Alexander v. Choate, 469 U.S. 287 (1985). 
companies to HIV infection. As epidemiologic evidence demonstrated the inexorable course of HIV infection, insurers began insisting on access to serologic information. Now much of the industry conducts its own HIV testing, and regards HIV infection as an uninsurable condition. ${ }^{164}$ Should genetic tests begin demonstrating the inevitability of future illness, we can expect insurers to follow the same course.

The ADA's major limitation on insurers, including self-insurers, is to prevent them from using underwriting as a subterfuge for invidious discrimination. ${ }^{165}$ Congress intended a liberal construction of the word "subterfuge," so that any evasion of the principles of anti-discrimination, whether malicious, purposeful or inadvertent, will be unlawful. ${ }^{166}$ Thus, insurers cannot completely deny health coverage on the basis of a genetic predisposition, and employers cannot deny a qualified applicant a job either because the employer's insurance plan does not cover the genetic disability or because of the increased cost. ${ }^{167}$ The sharp distinction drawn by the ADA is that any discrimination among disabled applicants for insurance or employment must be justified on the basis of actuarial data demonstrating a heightened risk of future illness. ${ }^{168}$

Whether one regards the ADA's exemption of underwriting as reasonable or not depends upon how the insurance industry is viewed. If the industry is regarded strictly as a business it is difficult to question the ability to discriminate on the basis of sound actuarial data. The very essence of underwriting is to classify people according to risk, treating those with higher risks differently. From a business perspective, no rational distinction can be drawn between genetic prognosis and smoking, hypertension, high serum cholesterol or HIV infection. In each case, medical data can provide powerful predictions of future health and longevity. Insurers also assert that access to genomic data is required to prevent "adverse selection." ${ }^{169}$ Perhaps the greatest fear

164 See generally Medical Testing and Health Insurance, supra note 38.

16542 U.S.C.A. $\$ 12201$ (c) (West Supp. 1990).

166 Congress rejected the Supreme Court's restrictive reading of the term "subterfuge" in Public Employment Retirement Sys. of Ohio v. Betts, 492 U.S. 158 (1989). The Court in Betts held that subterfuge required some malicious or purposeful intent to evade. See 136 Conc. Rec. H4614, 4623 (daily ed. July 13, 1990) (statement of Rep. Hawkins); id. at 4627 (statement of Rep. Waxman).

167 See H.R. REP. No. 485, supra note 80, pt. 2, at 82-83, reprinted in 1990 U.S. Code CoNG. \& Admin. News, at 364-66; id., pt. 3, at 35-36, reprinted in 1990 U.S. Code Conc. \& Admin. News, at 457-59.

16842 U.S.C.A. $\$ 12201$ (c)(2) (West Supp. 1990).

${ }^{169}$ Adverse selection refers to "[t]he tendency of persons with poorer than average health expectations to apply for or continue insurance to a greater extent than persons with average or better health expectations." Medical Testing and Health Insurance, supra note 38 , at vi. 
of insurers is that genetic testing will become common in clinical medicine yet they will be barred from obtaining that information.

If, on the other hand, the health insurance industry is viewed as an instrument of social policy, then the ADA's exemption of underwriting becomes worrisome. The social purpose of insurance is to spread risk across groups, enabling wider access to health care services. If health insurance becomes unavailable or unaffordable to those who are most likely to become ill, then the social purpose of insurance is thwarted.

Once the pool of applicants is a differentiated mass, and each person's medical future can be predicted with specificity, the conceptual foundations of the industry are inverted. It may not be too far in the future before a person's genome becomes a template for a wide array of diseases. If insurers choose to utilize genomic information to make sound actuarial predictions of disease, the ADA will be, in all probability, ineffective in placing any restrictions on the industry.

\section{Genetic Discrimination: Disparate Impact on Race, ETHNICITY OR GENDER}

Genetic prognosis, by its very nature, often disproportionately impacts vulnerable classes based on race, ethnicity, national origin or gender. Sickle cell is associated with persons of African heritage, TaySachs and Gaucher's disease (adult form) with Ashkenazi Jews, and Family Mediterranean Fever with Armenians. ${ }^{170}$ Risks of teratogenicity or congenital risks to the fetus are often focused on women or pregnant women, setting up a class based on gender.

Title VII of the Civil Rights Act of $1964^{171}$ prohibits job discrimination based upon race or gender unless the discriminatory practice is related to job performance. Lack of discriminatory purpose is irrelevant. ${ }^{172}$ Sandra Day O'Connor explained that the intention behind Title VII was "to prohibit an employer from singling out an employee by race or sex for the purpose of imposing a greater burden or denying an equal benefit because of a characteristic statistically identifiable with the group but empirically false in many individual cases." 173

The outcome of Title VII lawsuits is often dependent upon whether or not the racial or gender discrimination is intentional. If the class is explicitly race- or gender-based, or if the discrimination is intentional, the employer must prove its action is based upon a "bona fide

170 See supra notes 9-12 and accompanying text; see also T. DUSTER supra note 12, at 160 62.

17142 U.S.C. $\$ \S 2000 \mathrm{e}-2000 \mathrm{e}-15$ (1988).

172 See Smith v. Olin Chem. Corp., 555 F.2d 1283 (5th Cir. 1977).

173 Arizona Governing Comm. v. Norris, 463 U.S. 1073, 1108 (1983) (O'Connor, J., concurring). 
occupational qualification."174 Title VII also allows lawsuits based upon the disparate impact of a facially neutral policy. Once discriminatory effect is shown, the employer must only demonstrate that there was "business necessity" for the employment practice. ${ }^{175}$

Surprisingly little court litigation has focused on the burden of genetic testing on racial minorities or women. ${ }^{176}$ An immediate problem is that a genetic prognosis represents a facially neutral policy which does not expressly discriminate on the basis of race or gender. ${ }^{177}$ It is far more likely that Title VII litigation to remedy genetic discrimination will be based upon disparate impact theory, that the genetic trait or condition disqualifies proportionately more racial minorities or women.

\section{Sickle Cell Classification: A Form of Race Discrimination?}

Some courts have said in dicta that a job classification based upon sickle cell anemia or trait ${ }^{178}$ would create a disparate impact on African Americans. ${ }^{179}$ Yet no law suit has been successful under this theory. In Smith v. Olin Chemical Corporation, an African American employee brought a Title VII claim when he was fired due to current and future

17442 U.S.C. \& 2000e (1988).

175 Hayes v. Shelby Memorial Hosp., 726 F.2d 1543 (11th Cir. 1984); Wright v. Olin Corp., 697 F.2d 1172 (4th Cir. 1982). In 1989 the Supreme Court held that the plaintiff has the ultimate burden of proof, and that the employer need not demonstrate that the challenged practice is "essential" or "indispensable" to show business necessity. Wards Packing Co. v. Antonio, 490 U.S. 642 (1989). Congress has been trying, so far urisuccessfully, to repudiate the holding in Wards Cove.

176 Sickle cell lawsuits have been brought under many other theories which are not germane to employment discrimination. See Williams v. Treen, 671 F.2d 892 (5th Cir. 1982) (state prison officials' denial of treatment to persons with sickle cell anemia raises a constitutional issue); Taylor v. Flint Osteopathic Hosp., 561 F. Supp. 1152 (E.D. Mich. 1983) (finding against plaintiff who argued that black patients were discriminated against by being denied reimbursement for "unnecessary" medical treatments especially helpful for typically black problems); Ross v. Bounds, 373 F. Supp. 450 (E.D.N.C. 1974) (black inmates seeking injunctive relief if they had sickle cell anemia or trait did not state a cognizable claim under the Civil Rights Act).

${ }^{177}$ See EEOC v. Greyhound Lines, 635 F.2d 188 (3d Cir. 1980) (African American employee sued under Title VII alleging that no-beard policy adversely impacted black workers because of a skin condition particular to African Americans).

${ }^{178}$ Sickle cell anemia . . . is a devastating hereditary blood disorder, found almost exclusively in black populations, that can be traced to a defect in a single gene. Homozygotes, who inherit two copies of the mutant gene from their parents, suffer from painful, often life-threatening symptoms of sickle cell anemia. Heterozygotes, who inherit one mutant and one normal gene, are considered to have sickle cell trait .... [and] they show no clinical symptoms of sickle cell anemia.

D. Suzuki \& P. Knudtson, Genethics: The Clash Between the New Genetics and Human VALUES 144 (1989).

${ }^{179}$ See Narragansett Elec. Co. v. Rhode Island Comm'n for Hum. Rts., 118 R.I. 457, 374 A.2d 1022 (1977) (a sickle cell screen would clearly be discriminatory since no racial explanation was possible). Cf. General Electric Co. v. Gilbert, 429 U.S. 125, 153 n.5 (1977) (Brennan, J., dissenting) (under the majority opinion the employer could exclude sickle cell-related disabilities from its disability benefits plan and not violate Title VII). 
bone degeneration characteristic of sickle cell anemia. The Fifth Circuit rejected his claim that he was dismissed on account of his race, stating that the category of "bone degeneration" was racially neutral. The court also rejected arguments based upon disparate impact because of the "manifest job-relatedness of the requirement that a manual laborer have a good back." 180

Employment decisions based upon sickle cell trait may well violate Title VII. A class based upon sickle cell disproportionately impacts African Americans. Since the existence of a genetic trait usually does not indicate any current or future illness, it is difficult to conceive how employers would justify the discrimination as a business necessity.

\section{Fetal Protection Policies: A Form of Gender Discrimination?}

An employer's refusal to hire women of child-bearing age based upon the risk of teratogenicity or harms to the fetus in utero from occupational exposure may be easier to challenge because of a more direct gender classification, and less obvious job relatedness. Fetal protection policies, in one form or another, go back a long way. Earlier this century, the Supreme Court upheld exclusion of women from hazardous employment to protect the "future well-being of the race." 181 Since that time, however, a series of federal statutes set standards for employers to reduce toxic levels and other hazards to both men and women. ${ }^{182}$ The Pregnancy Discrimination Act of $1978^{183}$ amended Title VII to clarify that the statute prohibits "discrimination [against working women] on the basis of their childbearing capacity." 184

The Supreme Court has just decided the question of whether fetal protection policies are allowed under Title VII. In International Union, $U A W v$. Johnson Controls, ${ }^{185}$ the court held that sex-specific fetal protection policies are unlawful. The case concerned a battery manufacturer's policy that barred any woman from working in a job that exceeded preset lead levels, unless she presented medical evidence of sterility. ${ }^{186}$

180 Smith v. Olin Chem. Corp., 555 F.2d 1283 (5th Cir. 1977). See Peoples v. City of Salina, Kan., No. 88-4280-S, 1990 U.S. Dist. LEXIS 4070 (D. Kan. March 20, 1990) (rejecting claim of racial discrimination when a firefighter with sickle cell anemia was dismissed because of the heightened risk of sickle cell crisis; plaintiff was not qualified for the position).

181 Muller v. Oregon, 208 U.S. 412, 422 (1908).

182 See Fair Labor Standards Act, 29 U.S.C. $\$ \$ 201-219$ (1988); Occupational Safety and Health Act, 29 U.S.C. $\$ \$ 651$ - 687 (1988).

189 Pub. L. No. 95-555, 92 Stat. 2076 (codified as amended at 42 U.S.C. $\$ 2000$ e(k) (1988)).

184 Women affected in pregnancy, childbirth, or related medical conditions shall be treated the same as others who are "similar in their ability or inability to work." 42 U.S.C. $\S 2000 \mathrm{e}(\mathrm{K})$ (1988).

185 International Union, UAW v. Johnson Controls, Inc., 1991 US LEXIS 1715.

186 The pre-set levels were: (1) where any employee recorded a blood lead level exceeding 30ug/dl during the preceding year; or (2) the work site yielded an air sample during the 
The Seventh Circuit found no violation of Title VII. ${ }^{187}$ It reasoned that the fetal protection policy constituted a gender-neutral rule which had a disparate impact on a protected group. ${ }^{188}$ The policy was justified by the "business necessity" of preventing a "substantial health risk" to the children of female, but not male, workers. ${ }^{189}$

The Supreme Court found that Johnson Controls' fetal protection policy constituted facial discrimination, as it applied to female employees, but not to male employees. ${ }^{190}$ Such a policy could be justified only if sex were shown to be a "bona fide occupational qualification."191 The Court noted that the BFOQ defense is a narrow one, and that the legislative history and case law forbid discrimination against a woman because of her ability to become pregnant unless it interferes with her job performance. ${ }^{192}$

The Court also addressed the issue of potential harm to fetuses, stating that "[d]ecisions about the welfare of future children must be left to the parents who conceive, bear, support, and raise them rather than to the employers who hire the parents." 193 Ultimately, of course, the resolution of this ethical and legal dilemma is to reduce environmental hazards that harm both men and women, rather than excluding a class of persons deemed hypersusceptible. Allowing employers to "fix the worker, not the job," 194 would harm the public health. The Occupational Safety and Health Administration (OSHA) already mandates that employers maintain a workplace "free from recognized hazards that are causing or are likely to cause death or serious physical harm," and it requires the Secretary of Labor to promulgate health and safety standards, to the extent feasible, such "that no employee will suffer material impairment of health or functional capacity." 195 Private employers should not be permitted to make determinations about what is "safe" for whole subclasses of the employed population.

preceding year in excess of 30ug/dl. International Union, UAW v. Johnson Controls, Inc., 886 F.2d 871, 876 \& nn.7, 9 (7th Cir. 1989), rev'd, 1991 US LEXIS 1715.

187 ld. at 901 .

188 Id. at 885-901. See Hayes v. Shelby Memorial Hosp., 726 F.2d 1543 (11th Cir. 1984); Wright v. Olin Corp. 697 F.2d 1172, 1186 (4th Cir. 1982) ("the problem presented by a fetal protection policy involved motivations and consequences most closely resembling a disparate impact case").

189 Johnson Controls, 886 F.2d at 888, 899-901. See also Hayes, 726 F.2d at 1543.

190 Johnson Controls, 1991 US LEXIS 1715, *19.

191 Id. at $* 22$.

192 Id. at $* 32$.

193 Id. at $* 33$.

194 See Bertin, Fix the Job, Not the Worker, L.A. Times, Nov. 27, 1989, § B, at 7, col. 1.

195 Occupational Safety and Health Act (OSHA), 29 U.S.C. \& 655(b)(5) (1988). "OSHA has statutory authority to protect the fetuses of lead exposed working mothers . . . Harm to fetuses is a material impairment of the reproductive systems of parents." United Steelworkers of Am. v. Marshall, 647 F.2d 1189, 1256 n.96 (D.C. Cir. 1980), cert. denied, 453 U.S. 913 (1981). 
The fetal protection policy in Johnson Controls was directed more toward risks in utero than genetic risks. Suppose an employer discriminated against women only based upon' the teratogenicity of workplace toxins. Such a case would raise squarely the issue of whether teratogenic risks fall exclusively, or even predominantly, on women. Medical evidence that similar toxic exposure causes deformed sperm, also leading to birth defects, would surely result in a finding of intentional gender discrimination, since the brunt of the policy falls exclusively on women, but the risks are shared by both men and women. In such circumstances, Title VII would not tolerate consigning women to a class of employment with lower pay and potential based strictly on their ability to conceive.

\section{E. Genetic Specific State Anti-Discrimination Statutes}

A minority of states have enacted statutes which specifically apply to persons with hereditary conditions. ${ }^{196}$ The most progressive of these statutes recognize that disease-specific legislation might prove too rigid as scientific understanding of the human genome progresses. ${ }^{197}$ These statutes have broad application to "any hereditary disorder, ${ }^{198}$ and they draw the distinction between carriers and those who experience manifestations of the disease. ${ }^{199}$ Other statutes are directed more narrowly to specific conditions or traits such as sickle cell, ${ }^{200}$ PKU, hemophilia, cystic fibrosis, Tay-Sachs or Cooley's anemia. ${ }^{201}$

These various statutes do not appear to follow any coherent policy or pattern. Only a few ban discrimination. California adopted a general anti-discrimination policy which includes penalties for violating the Hereditary Disorders Act of 1990. The California statute is comprehensive and prohibits "stigmatization" and "discrimination" against "carriers of most deleterious genes." It also proscribes mandated state

196 Cal. Health \& SAfety Code $\$$ 150, 151, 155, 309, 341 (West 1990); 1990 Cal. Senate Bill 1008 (ch. 26); Fla. Stat. \$ 385.206 (1989); Illinois 1990 Public Act 86-1028; IowA Code $\$ 136$ A.2 (1989); LA. Rev. Stat. AnN. \$ 46.2254 (West 1982); Md. Health-Gen. Code ANN. \$ 13-101; Mo. Rev. Stat. \& 191 (1989); N.J. Rev. Stat. \& 26:5B-3 (1987); 1990 N.Y. LaWs 900; VA. Code ANN. \& 32.1-68. (1990).

197 Cal. Health \& Safety Code $\$ 150$ (West 1990).

198 See, e.g., id; N.J. Rev. Stat. \$ 26:5B (1987); N.J. Stat. AnN. \& 10:5-12a (West Supp. 1990) (any "atypical hereditary or blood trait").

199 Cal. Health \& Safety Code $\$ 150$ (West 1990).

200 FLA. STAT. \$ 448.075 (1989) (prohibits testing for sickle cell but no other genetic trait or disease); id. at $\$ 385.206$ (1989) (singles out sickle cell and hemophilia for medical care grants); La. Rev. Stat. ANN. $\$ 46.2254$ (West 1982) (prohibits employment discrimination only with regard to sickle cell).

201 See Mo. Rev. Stat. §191.3 (Supp. 1991) (defines genetic and metabolic disease programs to include those concerning cystic fibrosis, hemophilia, and sickle cell); 1990 N.Y. LAws 900 (including sickle cell, Tay-Sachs or Cooley's anemia). 
restrictions on child-bearing decisions regardless of the genetic purpose. ${ }^{202}$

Statutes in Florida, Illinois, Louisiana, New Jersey, New York and North Carolina are patterned after disability law and prohibit employment discrimination against persons with any "atypical hereditary or blood trait" ${ }^{203}$ or particular genetic conditions or traits. ${ }^{204}$ In some cases the statutes have general application beyond employment discrimination, including disparate impact on racial or ethnic minorities, ${ }^{205}$ or discrimination on the basis of familial status when in the process of securing legal custody. ${ }^{206}$

The remainder of the genetic statutes prohibit certain types of screening, ${ }^{207}$ provide funding for research or treatment, ${ }^{208}$ or require mandatory information on genetic disorders to be given to marriage applicants. ${ }^{209}$ Others are concerned with genetic counseling and confidentiality. ${ }^{210}$

A review of current state statutes reveals a patchwork of provisions which are incomplete, even inconsistent, and which fail to follow a coherent vision for genetic screening, counseling, treatment and prevention of discrimination.

\section{CONCLUSION: FUTURE LEGAL SAFEGUARDS AGAINST GENETIC DISCRIMINATION}

The course currently charted by the Human Genome Initiative is filled with the promise of unimagined medical advancement for humankind. The potential harm to human beings by rendering them virtually unemployable or uninsurable may be equally real. ${ }^{211}$ Policy makers should consider legal strategies to prevent such genetic discrimination. While the ADA is a powerful tool to combat genetic discrimination, its construction should not be left to the uncertainty of future judicial decisions. The ADA specifically redresses discrimination based upon past disability ("record of impairment"), current disability ("impairment") or perception of disability ("regarded" as impaired). The ADA, how-

202 Cal. Health \& Safety Code $\$ 150$ (West 1990).

203 See, e.g., N.J. Stat. Ann. \$ 10:5-12a (West Supp. 1990).

${ }^{204}$ See, e.g., Fla. Stat. ANN. $\$ 448.075$ (1981) ("No person, firm, corporation, . . state agency, . . or any public or private entity shall deny or refuse employment to any person or discharge any person from employment solely because such person has the sickle cell trait.").

205 Illinois 1990 Public Act 86-1028, S.B. No. 1466.

206 Id.

${ }^{207}$ E.g., Fla. Stat. ANn. $\$ 448.075$ (West 1988) (prohibiting testing for sickle cell).

${ }^{208}$ E.g., id. at $\$ 385.206$ (1989); IoWA CODE $\S 136$ A.2 (1989).

209 Ill. 1990 Public Act 86-1028, S.B. No. 1466.

210 Mo. ANN. Stat. $\$ \$ 191.317,191.320$ (Vernon Supp. 1991).

211 See genetally D. Nelkin \& L. Tancredi, Dangerous Diagnostics: The Social Power of Biological INFORMATION (1989). 
ever, is silent about discrimination based upon future disability. While this paper has presented a number of legal, ethical and public policy arguments to suggest that future disability is covered, a simple amendment to section three of the ADA would remove any uncertainty. A new subsection, "D," could amend the definition of disability to include: "having a genetic or other medically identified potential of, or predisposition toward, such an impairment." Such language would ensure that discrimination against currently asymptomatic persons based upon a future prediction of disease would be covered by the ADA.

There remains in the ADA one major gap that is not so easily rectified: the exclusion of underwriting from the coverage of the Act. Future regulations under the ADA should seek to ensure that employers do not use this underwriting exclusion to discriminate against applicants or employees because of likely financial burdens to employer benefits plans. Employers may well turn to imaginative actuarial justifications for invidious discrimination. Additionally, employers may not need to take the drastic measure of not employing a person, as they may make the benefits plan so unattractive and unaffordable that it may act as a formidable barrier to disabled persons.

Strict regulations preventing employers from evading the principles of the ADA are only a stop gap remedy. Ultimately, a political choice will have to be made by Congress as to whether insurers and self-insurers are merely businesses, or facilitators of wider social goals. If insurance discrimination rises to a truly unconscionable level as the genome is mapped, then society may have to confront the issue of access to health care.

Gaps in the coverage of disability law also need to be addressed at the state level. State disability laws should be amended to clarify their coverage of future disabilities. The continuing importance of state disability laws cannot be underestimated given their more efficient administrative structures, and greater resources to combat discrimination.

Policy makers will also have to confront the philosophic and pragmatic issue of whether genetic-specific legislation is necessary or desirable. The great majority of state legislatures have enacted HIV-specific legislation, ${ }^{212}$ so the precedent is set for separately addressing particularly vexing national public health problems. The National Human Genome Initiative should give careful consideration to developing a set of legislative guidelines. In the absence of such guidelines, the prospect for rational legislation appears low.

Model guidelines on the law and ethics of genetic screening, confidentiality and discrimination ought to go hand-in-hand with scientific

212 See Public Health Strategies for Confronting AIDS, supra note 65, at 1621. 
advances. Funding, original thinking and carefully crafted policy on the legal and ethical dimensions of the Human Genome Project are as essential as the science itself. 